\title{
Web-Based Sales and Fundraising Information System at Beri Perubahan Indonesia Foundation
}

\author{
Arpan $^{1}$, Muhammad Arif Furqon ${ }^{2}$ \\ ${ }^{1,2}$ Faculty of Science and Technology, University of Development Panca Budi, Medan, Indonesia \\ Corresponding Author: Arpan
}

\begin{abstract}
This research departs from the problems faced by the management of Beri Perubahan Indonesia Foundation, namely (1) The absence of an information system that acts as a Transaction Processing System (TPS), (2) The absence of an information system that provides the best convenience and experience for users and donors in Beri Perubahan Indonesia Foundation equipped with payment gateways so that users are facilitated in every transaction they make. Based on these problems, researchers aim to solve existing problems. In this study researchers used descriptive qualitative research motto using primary data from unstructured interview results and secondary data derived from library studies, while to build the required system, researchers used one type of Agile method, namely Extreme Programming (XP).

Based on the results of the study, it shows that researchers successfully fulfilled the purpose of this study or in a sense, with this study Beri Perubahan Indonesia Foundation already has an information system that acts as a Transaction Processing System (TPS) to manage sales and also fundraising or crowdfunding, and there has been a system that provides convenience and a good experience for users and donors at Beri Perubahan Indonesia Foundation. But in the article management section, the system has not been able to login one door, so to enter the Content Management System (CMS) page of the article, must login again. In the end, the sales and fundraising information system created and designed by researchers has met the research objectives and meets the needs of Beri Perubahan Indonesia Foundation.
\end{abstract}

Keywords: Agile, Crowdfunding, Payment Gateway, Content Management System.

\section{INTRODUCTION}

An information system is defined as a set of interrelated components that work together to perform input, processing, output, storage, and control operations to convert data into information products that can be used to support prediction, planning, control, coordination, and decision-making and organize operational activities within the organization (Romindo, et al., 2020).

Beri Perubahan Indonesia Foundation is a foundation engaged in education and social through activities held both through cyberspace and real, which focuses on the growth of good habits, selfdevelopment, expanding educational opportunities for the nation's children and fundraising for education, health and social.

The growth of Beri Perubahan Indonesia Foundation which is characterized by the large number of followers and fans of classes or events which are products of Beri Perubahan Indonesia Foundation and the growth of the number of donors both through donation campaigns and social events, but not balanced by the existence of a system that helps manage the data, thus making the existing data can not be utilized properly, Not only that, because of the absence of a system that manages existing processes, making minimal resources at Beri Perubahan Indonesia Foundation focused on technical matters that often provide counterproductive busyness, so many strategic plans are not on time.

On the other hand, users need a good website, which can make users feel 
comfortable and happy in interacting with the Website of Beri Perubahan Indonesia Foundation, in addition it is also needed to give a good impression to users, so that user confidence will increase.

\section{LITERATURE REVIEW INFORMATION SYSTEMS}

A system is a collection of people who cooperate with each other through systematic and structured rules to form a single entity that performs functions to achieve goals. The system has several characteristics or attributes, including system components, system limitations, external environment, system connections, system input, system output, system processing and system objectives.

Information is data that has been processed to be more useful and meaningful to the recipient, and reduce uncertainty in the decision-making process for the situation. An information system is a regular combination of personnel, hardware, software, communication networks, and data sources that can collect, modify, and disseminate information within an organization (Anggraeni \&Irviani, 2017).

\section{SALES}

Sales are an important component in the operation of a company, so the company must be able to provide the best service to customers. A sales system is a system that involves resources in an organization, procedures, data, and supporting facilities to operate the sales system, thus generating information that is useful for management in decision making (Hidayati, 2019).

\section{FUNDRAISING (CROWDFUNDING)}

Crowdfunding is the practice of fundraising for various types of businesses, whether in the form of product ideas, businesses or activities whose funds are obtained from the donation of the general public or groups (Riskiono, Hamidy, \& Ulfia, 2020).
The concept of crowdfunding can be applied today due to several factors (Fadjri, Ilhamsyah, \& Prawira, 2019), namely;

- More and more people are trusting online payment methods through online media.

- Social networks are increasingly allowing people to communicate with each other to their connections easily.

- Today's technology allows online payments to be made securely.

- Communities can easily meet together online to start a specific project or initiation.

- Other success stories related to projects or initiatives funded by crowdfunding.

\section{WEB}

World Wide Web (WWW) or also called the web is one of the services obtained by computer users connected to the internet. The web provides information for computer users connected to the internet ranging from "junk" information or completely useless information to serious information, from free information to commercial information. A website or site can be defined as a collection of pages used to display text, still or motion images, animations, sounds, or a combination of both static and dynamic that form a series of interrelated buildings in which each is linked by a network page (hyperlink) (Sa'ad, 2020).

According to Suwanto Raharjo S.Si, M.Kom, the Web is one of the most widely used internet services compared to other services such as FTP, gopher, news or even email.

\section{PAYMENT GATEWAY}

Payment Gateway Service is a thirdparty service that connects merchants with banks. With the availability of these services, merchants can provide online payment services on their online shopping websites by connecting their websites to payment gateway services using the services of the Application Program Interface (API). Payment gateway services are needed 
because of the high initial cost and maintenance costs to connect with banks, in addition, a system that can connect bank accounts from customers and merchants (Husein, Akbar, Hisham, \& Legowo, 2019).

\section{LARA VEL}

Laravel is an MVC web development framework (Model View Controller) designed to improve software quality by reducing development and repair costs as well as increasing work productivity with a clean and functional syntax that can reduce a lot of time for implementation, in addition Laravel is a PHP framework that emphasizes simplicity and flexibility in its design (Luthfi, 2017).

\section{UNIFIED MODELLING LANGUAGE (UML)}

UML (Unified Modelling Language) is a graphics/image-based language for visualizing, defining, building, and documenting software development systems. UML itself also provides standards for writing blue print systems, which include business process concepts, writing classes in certain programming languages, database schemas, and components needed in a software system (Mubarak, 2019).

\section{ENTITY RELATIONSHIP DIAGRAM (ERD)}

ERD describes a model of entity relationships that are a combination of concepts, attributes, and relationships between entities, as well as entities in the ERD representing something or object in the real world. AN ERD is a diagram that describes the relationships between relevant entities of system interests.

To create an Entity Relationship Diagram or ERD, there are three main components or notations, namely entities, attributes, and relationships. An entity is a real-world object that can be distinguished from all other objects (Ginantra, et al., 2020).

\section{JAVASCRIPT OBJECT NOTATION (JSON)}

JSON (Javascript Object Notation) is a lightweight data exchange format, easy to read and write by humans, and easily translated and created by computers.

JSON is a text format that does not rely on any programming language because it uses the language styles commonly used by $\mathrm{C}$ family programmers including $\mathrm{C}, \mathrm{C \#}$, Java, JavaScript, Perl, Python etc. (Buwono, 2019).

\section{APLICATION PROGRAMMING INTERFACE (API)}

An API is not a database or even a server, an API is the code that sets the access point for its server, usually returning data or responding in JSON or XML format (Eising, 2017).

\section{WEBHOOK}

Webhook is closely related to the web API, where after we send data, apIs that require webhook features will ask for URL data as endpoints to receive data that will be sent by the service provider. For example, when using a payment gateway, we are required to send a callback URL, this is used so that when there is an incoming payment and payment gateway sends data to our website, the website is ready to receive with the webhook, so that the payment data on our website is also updated in real time.

\section{AGILE}

Agile is a way of developing software with various small looping processes or often called iterations (Ismail, 2021).

In contrast to the Waterfall methodology, we must have a linear flow from start to finish that cannot be cut or changed in the middle of the process. While the principle of Agile is flexibility in every change, so that when there are small changes do not repeat the process from the beginning as is the case with the Waterfall method. 


\section{MATERIALS \& METHODS METHODOLOGY}

System development in this study uses the Extreme Programming (XP) model. Extreme Programming is a model included in the agile approach introduced by Kent Back. Extreme Programming (XP) is a software development method that is fast, efficient, low-risk, flexible, predictable, scientific, and fun (Michael, 2015).

The stages that must be passed include: Planning (Planning), Design (Design), Coding (Coding), and Testing (Testing).

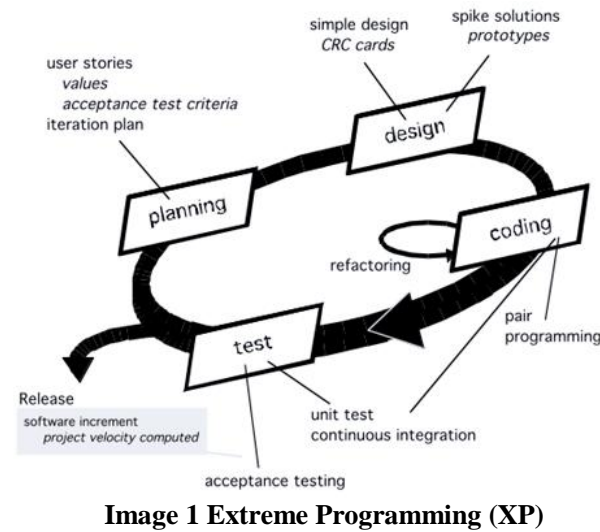

ANALYSIS OF THE SALES PROCESS

The sales process in question is the process of selling the event at Beri Perubahan Indonesia Foundation, starting from the admin side to how the process of buying the event by the buyer

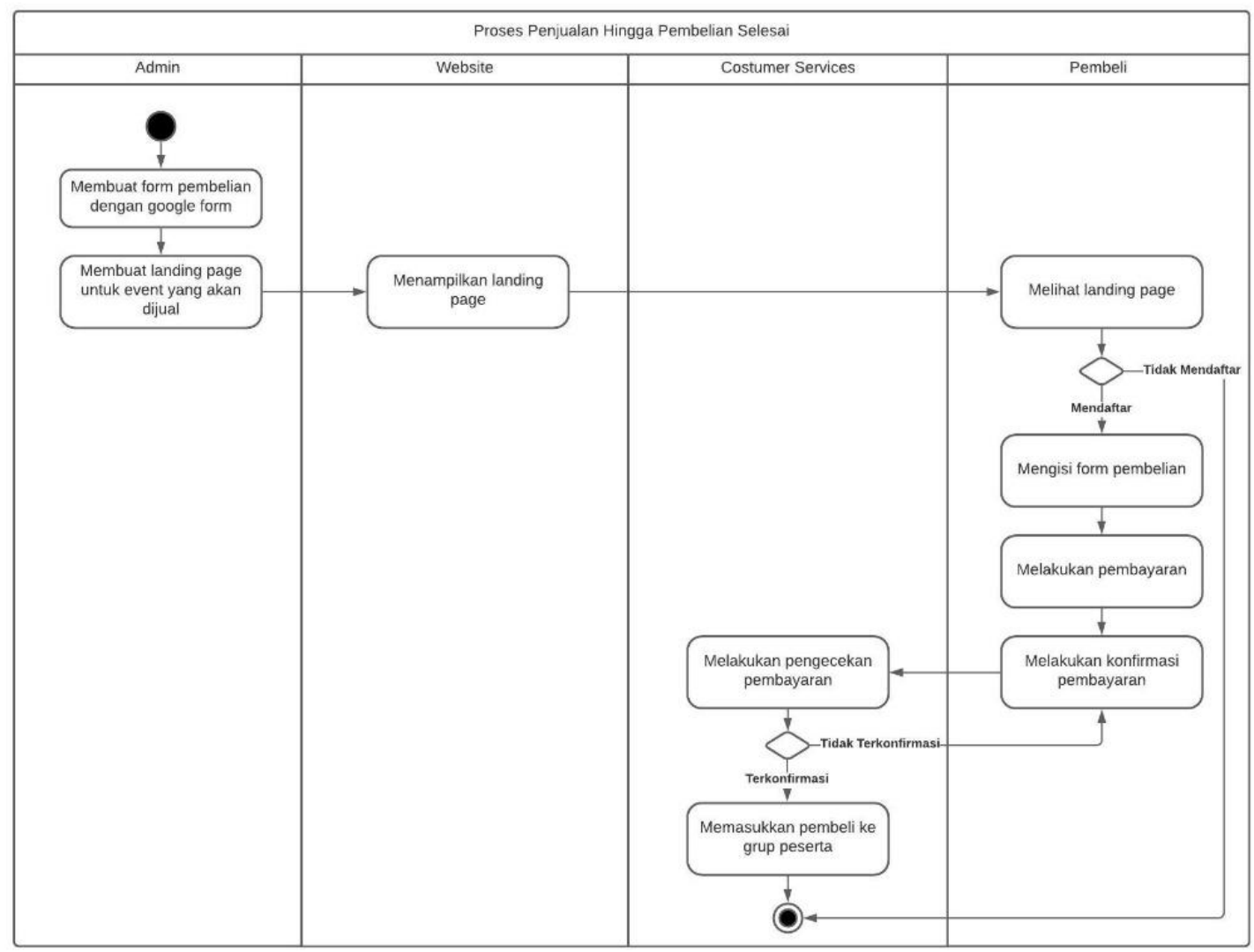

Image 2. Activity Diagram of The Sales Process

\section{ANALYSIS OF THE FUNDRAISING PROCESS}

The fundraising process (crowdfunding) is a fundraising process at Beri Perubahan Indonesia Foundation, starting from the admin side to how the donor process makes the donation. 


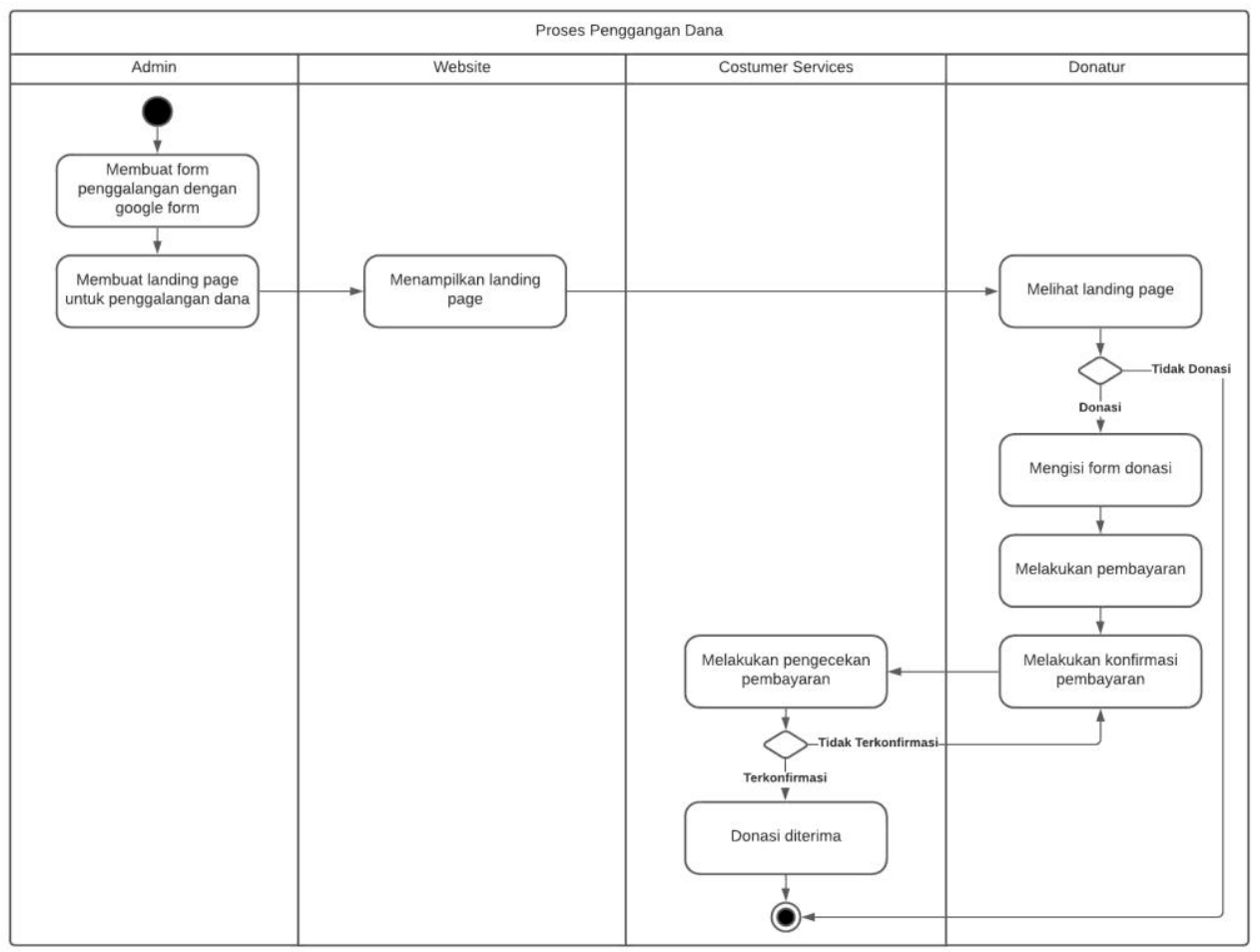

Image 3 Activity Diagram of the Fundraising Process

\section{Analysis of Report Creation Process}

The process of making a report at Beri Perubahan Indonesia Foundation, both sales and fundraising reports is the same process.

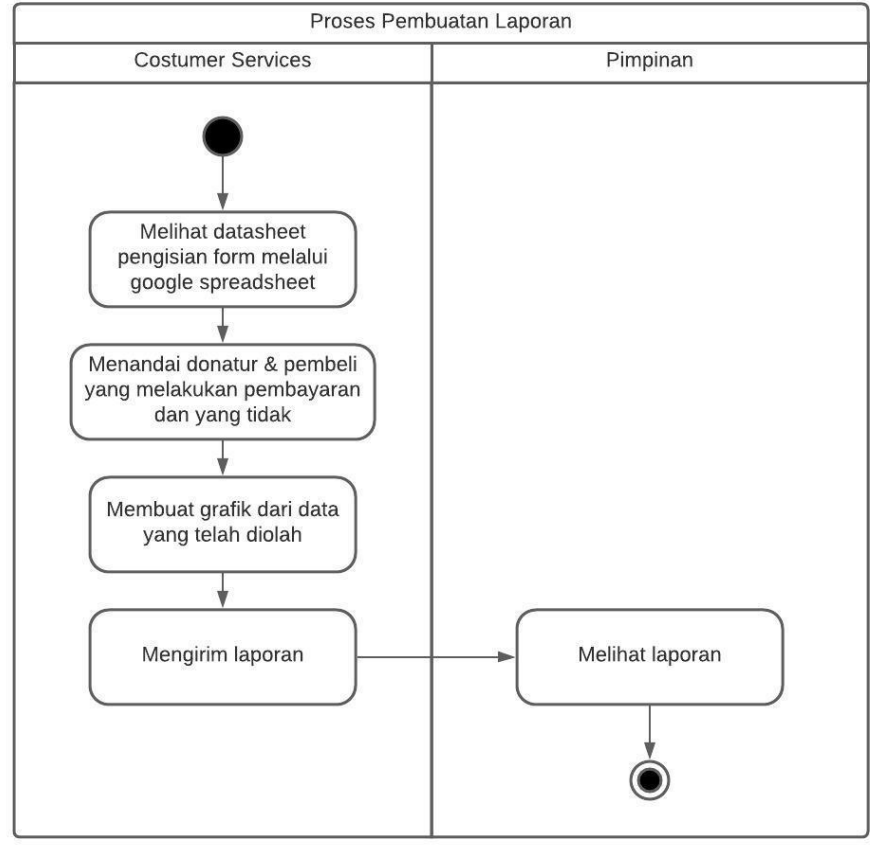

Image 4 Activity Diagram report creation process

\section{System Needs Analysis}

At this stage the author first conducts an unstructured interview by giving the Beri Perubahan Indonesia Foundation the opportunity to reveal the problem and the final result of the need, after completion, the author converts from the story told by the Beri Perubahan 
Indonesia Foundation into features that will be applied to the system to be developed, this is made so that the final results and goals of system development become clear and objective, All parties have the same goal.

\begin{tabular}{|c|c|c|c|c|}
\hline \multirow{2}{*}{$\begin{array}{l}\text { Authentication Dan } \\
\text { Authorization }\end{array}$} & Event & Campaign & Artikel & $\cdots$ \\
\hline & Index Data Event & Index Data Campaign & \multirow{2}{*}{\multicolumn{2}{|c|}{$\begin{array}{l}\text { Buat Content management system } \\
\text { (CMS) postingan }\end{array}$}} \\
\hline Fitur Login dan Register & & & & \\
\hline \multirow{2}{*}{$\begin{array}{l}\text { Multilevel Role (Super Admin, Admin, } \\
\text { dan Member) }\end{array}$} & Buat Event & Buat Campaign & \multirow{2}{*}{\multicolumn{2}{|c|}{$\begin{array}{l}\text { Menampilkan postingan pada } \\
\text { halaman depan untuk publik }\end{array}$}} \\
\hline & Edit Event & Edit Campaign & & \\
\hline $\begin{array}{l}\text { Admin : mengelola event dan } \\
\text { campaign, bisa donasi }\end{array}$ & Hapus Event & Hapus Campaign & + Add another card & 策 \\
\hline $\begin{array}{l}\text { Super admin : semua kebiasaan } \\
\text { admin dan bisa mengelola pengguna }\end{array}$ & $\begin{array}{l}\text { Pembelian Event bisa bersifat } \\
\text { berbayar, bisa bersifat donasi atau } \\
\text { event sosial, pembayaran }\end{array}$ & $\begin{array}{l}\text { Proses Donasi, pembayaran } \\
\text { menggunakan payment gateway }\end{array}$ & Riwayat Transaksi & .. \\
\hline \multirow{2}{*}{$\begin{array}{l}\text { Member : Hanya bisa melihat event } \\
\text { yg telah dibeli, dan bisa donasi }\end{array}$} & menggunakan payment gateway & $\begin{array}{l}\text { Laporan Campaign ringkasan dan } \\
\text { grafik chart }\end{array}$ & $\begin{array}{l}\text { Menampilkam data transaksi } \\
\text { pembelian event dan donasi }\end{array}$ & \\
\hline & Laporan Event ringkasan dan grafik & & Fitur cetak invoice di transaksi & \\
\hline \multirow[t]{2}{*}{ + Add another card } & chart & Tabel data donatur & $\begin{array}{l}\text { Fitur cetak Invoice di transaksi } \\
\text { berhasil }\end{array}$ & \\
\hline & Tabel data peserta & $\begin{array}{l}\text { Tabel data donatur yang belum } \\
\text { menyelesaikan pembayaran }\end{array}$ & \multirow{2}{*}{\multicolumn{2}{|c|}{$\begin{array}{l}\text { Fitur melihat nomor pembayaran } \\
\text { kembali di transaksi pending }\end{array}$}} \\
\hline Manajemen Pengguna & \multirow{3}{*}{$\begin{array}{l}\text { Tabel data peserta yang belum } \\
\text { menyelesaikan pembayaran }\end{array}$} & \multirow{2}{*}{$\begin{array}{l}\text { Tombol redirect ke whatsapp yang } \\
\text { digunakan buat follow up agar } \\
\text { melakukan pembayaran }\end{array}$} & & \\
\hline $\begin{array}{l}\text { Super Admin bisa mengubah jenis } \\
\text { pengguna }\end{array}$ & & & + Add another card & 当 \\
\hline + Add another card & & \multirow{2}{*}{$\begin{array}{l}\text { Menampilkan detail campaign untuk } \\
\text { publik serta menampilkan data } \\
\text { donasi yang sudah dibayar }\end{array}$} & Sertifikat & $\cdots$ \\
\hline Review & Menampilkan event di halaman & & \multicolumn{2}{|l|}{$\begin{array}{l}\text { Fitur cetak sertifikat bagi yang ikut } \\
\text { event }\end{array}$} \\
\hline $\begin{array}{l}\text { Fitur melakukan review bagi yg ikut } \\
\text { event }\end{array}$ & + Add another card & + Add another card & \multicolumn{2}{|l|}{ Fitur cek keaslian sertifikat } \\
\hline & & & + Add another card & 管 \\
\hline
\end{tabular}

The analysis of system needs based on system weaknesses is running and based on user stories at Beri Perubahan Indonesia Foundation is as follows:

- Authentication and Authorization Needs

- Event Section Needs

- Campaign Section Needs

- Article Section Needs

- Transaction History Section Needs

- User Management Section Needs

- Review Section Needs

- Additional Needs

\section{SYSTEM DESIGN}

Based on the results of the system needs analysis, unified modeling language (UML) is produced as follows:

A use case diagram is one of the different types of UML (Unified Modeling Language) diagrams that describe the interaction relationship between systems and actors. Use cases can describe the type of interaction between the user and the system. Here is a use case diagram of the system to be created:

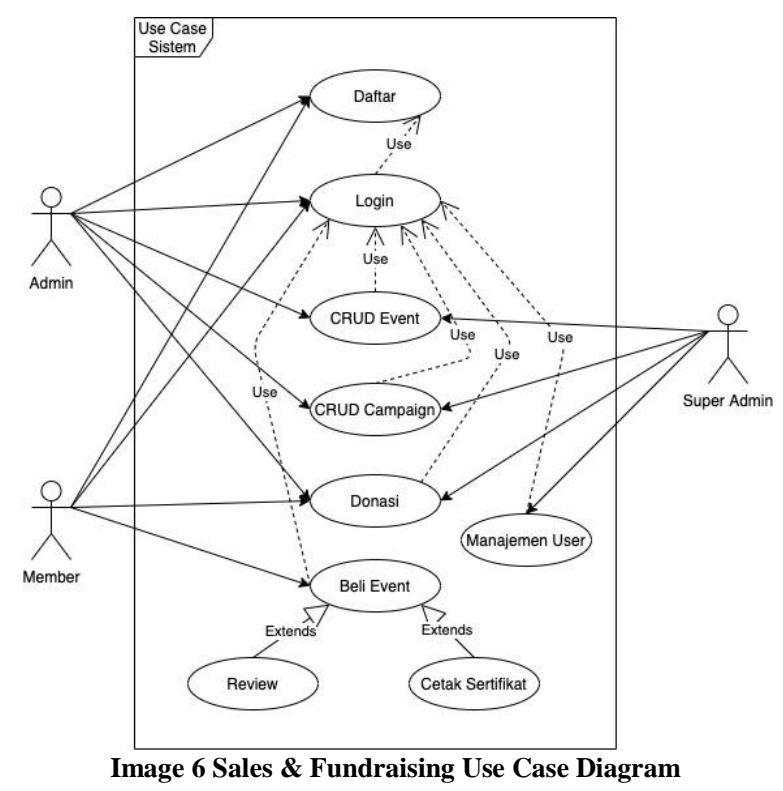

\section{DATABASE PLAN}

In the process of designing this database, the author uses an entity relationship diagram (ERD) to describe the entities in the system as well as the 


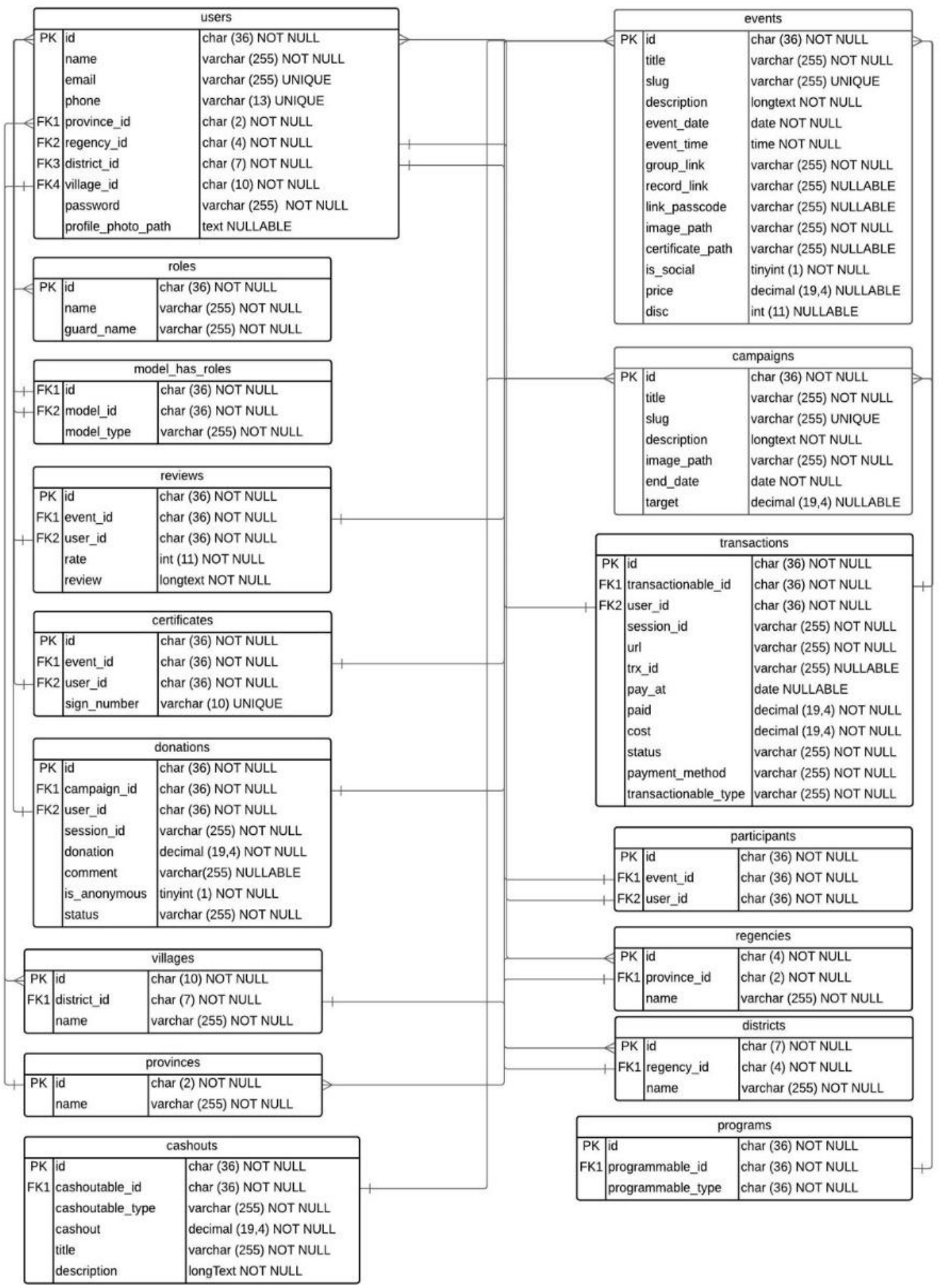

Image 7 Entity Relationship Diagram System

\section{DISPLAY DESIGN}

At this stage the researchers create a display design that will be used as a reference to create a display on the system to be made. It aims to facilitate the design process. Here is the system display design: 

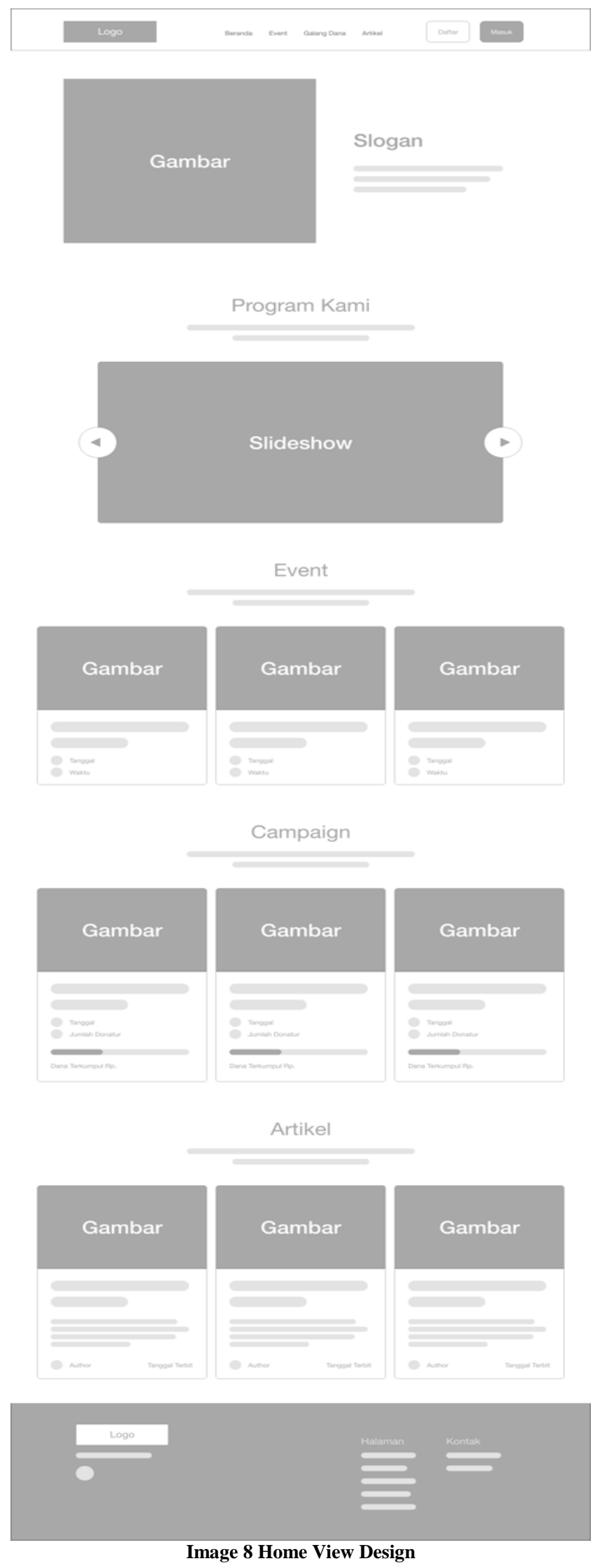

\section{LOGIN VIEW}

Here are the details of the view from the loginpage: 


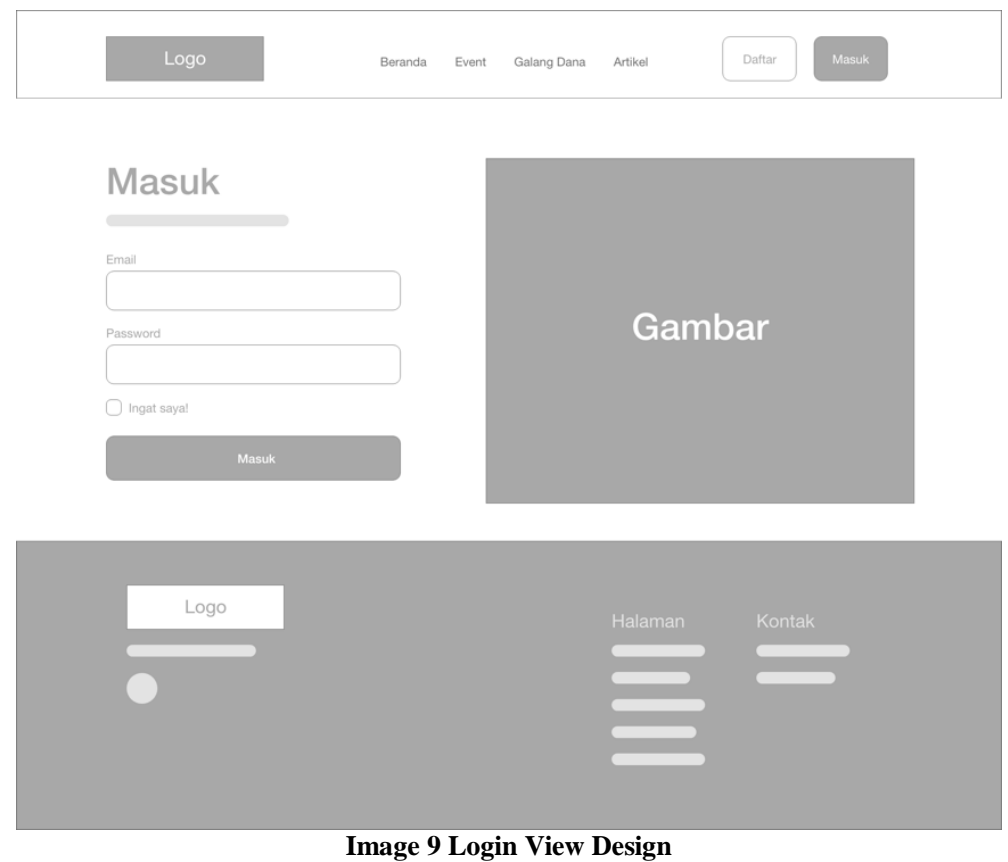

\section{LIST VIEW (REGISTER)}

Here are the details of the display design from the list or registration:

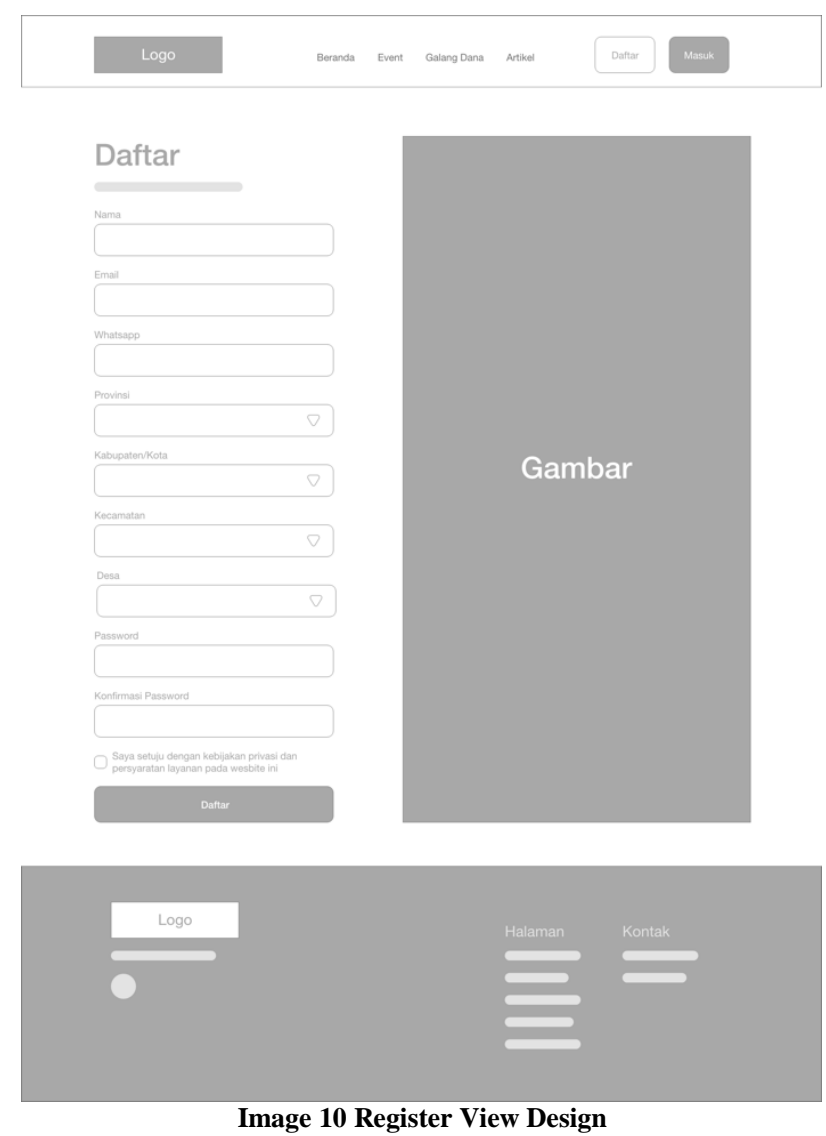

\section{RESULT AND DISCUSSION}

AUTHENTICATION AUTHORIZATION PROCESS AND TESTING

This section of the list is the part where the user registers on the system, so that the system can recognize the user who will later login to this system. Although there are 3 types 
of users, namely super admin, admin and member, by default this section of the list will register users to be a type of member user for security reasons. Here's a list or registration page view:

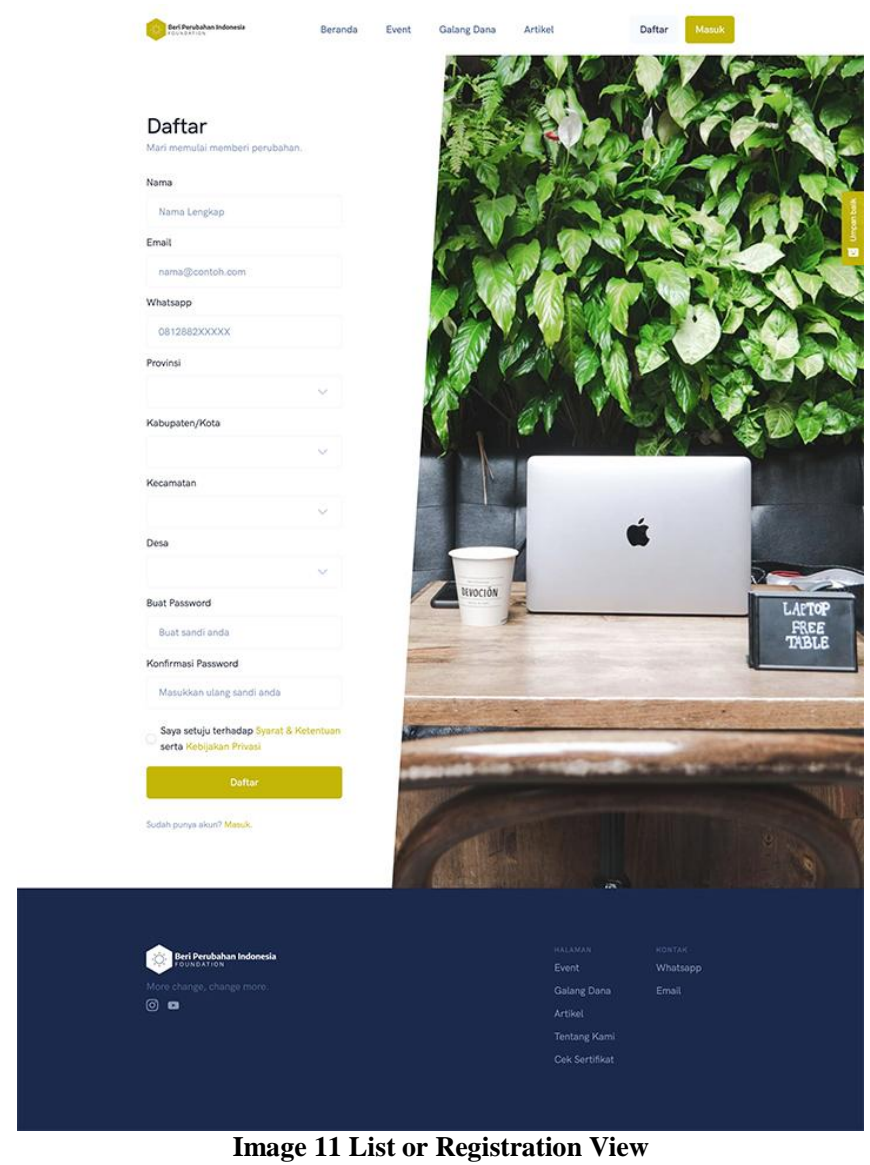

This login section is the main gateway used by all types of users to enter the system. In this login section users are required to fill in an email and password and submit or login. Then the system will check the email and password and the system will recognize the type of user through the data inputted at the time of login, so that each user recognized by the system will be directed to the main page according to the type of user. Here's a look at the login or login page:

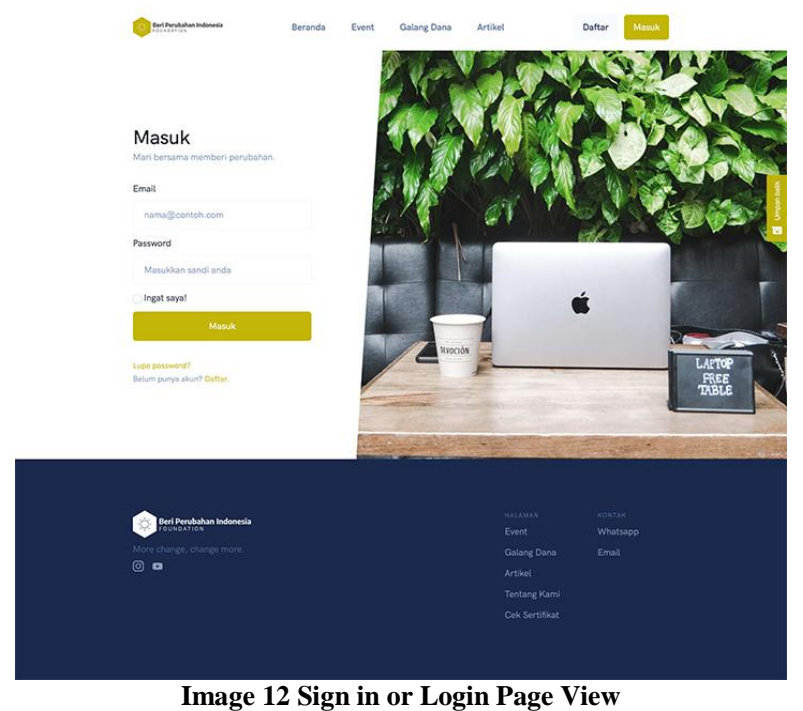




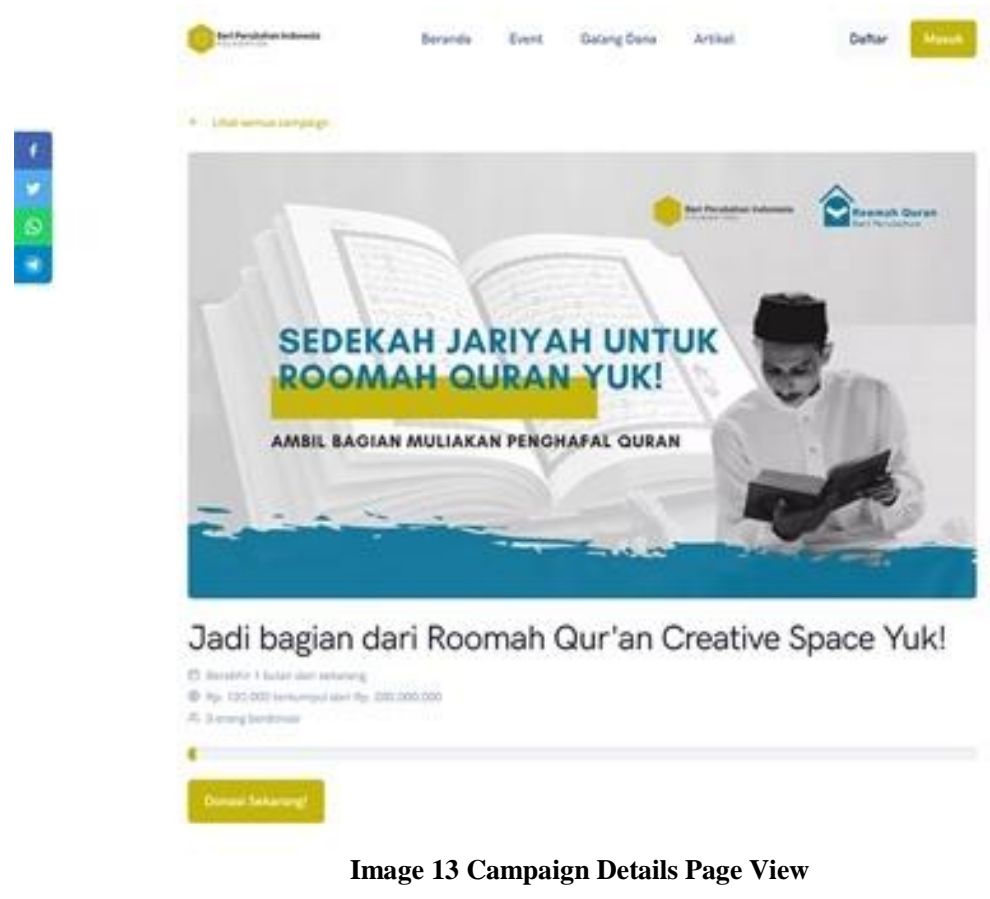

\section{CONCLUSION}

Based on the results of research conducted with descriptive qualitative research methods and extreme programming system development (XP) methods at Beri Perubahan Indonesia Foundation, the authors concluded that this study has achieved the expected objectives, namely:

- The existence of a web-based Transaction Processing System (TPS) is equipped with a payment gateway at Beri Perubahan Indonesia Foundation, and has been in accordance with the research design presented by the author;

- With the system built based on good scientific rules and refers to the results and discussions, it can be concluded that website users are facilitated in carrying out transaction processes compared to before the existence of this system.

Not only that, with this web-based system, users of the Beri Perubahan Indonesia Foundation website can also express their creativity by writing articles, so that this system is not only intended for business management and donations, but also accommodates young people to always work.

For Beri Perubahan Indonesia Foundation, this system provides ease of transaction management, both sales transactions and donation transactions, so that existing human resources are more focused on executing strategic plans and no longer bus bused with technical matters that are exhausting and counter-productive.

For the authors, this study provides a lot of learning, especially about the implementation of payment gateways on a system and how to secure webhook that there could be people who want to intend evil, but it can be overcome with careful planning and balanced by good problemsolving logic, especially this system is widely used by Beri Perubahan Indonesia Foundation for the public good.

Acknowledgement: None

Conflict of Interest: None

Source of Funding: None

\section{REFERENCES}

1. Anggraeni, E. Y., \& Irviani, L. (2017). Introduction to Information Systems. Yogyakarta: ANDI.

2. Buwono, R.C. (2019). Web Services Using JSON Format. Journal of Information Technology,1-10.

3. Eising, P. (2017, December 12). What Exactly is an API?. Retrieved June 4, 2021, 
from

Medium:

https://medium.com/@ perrysetgo/what-

exactly-is-an-api-69f36968a41f

4. Fadjri, D., Ilhamsyah, \& Prawira, D. (2019). Design Build An Orphanage Fundraising Information System using crowdfunding methods with a Donation Site Model. Journal of Computers and Applications,6473.

5. Fatta, H. A. (2017). Analysis \&Design of Information Systems for competitive Advantages of Modern Companies \&organizations. Yogyakarta: Andi.

6. Ginantra, N. W., Wardani, N. W., Aristamy, I. A., Suryawan, I. D., Sudipa, I. I., Ardiana, D. P., . . Parwita, W. G. (2020). Database of Theory and Planning. Field: Our Foundation Writes.

7. Heath, M. (2017, March 6). A Basic Introduction to Webhooks. Retrieved June 4, 2021, from Sound Code: https://markheath.net/post/basicintroduction-webhooks

8. Hidayati, N. (2019). Use of Waterfall Method in Designing Sales Information System. Generation Journal,1-9.

9. Husein, Akbar, H., Hisham, M. N., \& Legowo, M.B. (2019). Payment Gateway on E-Canteen Website Application. International Journal of Progressive Sciences and Technologies (IJPSAT),108112.

10. Ismail, I. (2021, April 19). Agile is a project management method that focuses on users. Retrieved 4 June 2021, from Accurate: https://accurate.id/marketingmanajemen/agile-adalah/
11. Luthfi, F. (2017). Use of Laravel Framework In Designing Back-End Modules of Bisnisbisnis.ID Website Articles. Journal of Informatics Sunan Kalijaga,34-41.

12. Michael. (2015, December18). Extreme Programming. Retrieved May 24, 2021, from Medium: https://medium.com/@ mikesebastian/extre me-programming-c715e6b8e0e9

13. Mubarak, A. (2019). Design School Web Applications Using Uml (Unified Modeling Language) And Object-Oriented Php Programming Languages (Php Hypertext Preprocessors). Journal of Informatics and Computers, 19-25.

14. Riskiono, S. D., Hamidy, F., \& Ulfia, T. (2020). Web-Based Donor Fund Management Information System At Yatim Madani Orphanage. Journal of Social and Technology for Community Service (JSTCS), 21-26.

15. Romindo, Niar, H., Sipayung, R., Yendrianof, J. D., Peru, M. F., Febrianty, . . . Purba, B. (2020). Business Information Systems. Field: Our Foundation Writes.

16. Sa'ad, M. I. (2020). Self-taught Web Programming: Creating an Edutainment Website. Jakarta: PT Elex Media Komputindo.

How to cite this article: Arpan, Furqon MA. Web-based sales and fundraising information system at Beri Perubahan Indonesia foundation. International Journal of Research and Review. 2021; 8(10): 230-241. DOI: https://doi.org/10. 52403/ijrr.20211030 